\title{
Entomological survey for identification of Aedes larval breeding sites and their distribution in Chattogram, Bangladesh
}

\author{
Md. Sahidur Rahman ${ }^{1,2^{*}}$, Md. Omar Faruk ${ }^{3}$, Sumiya Tanjila', Nur Mohammad Sabbir ${ }^{1}$, Najmul Haider ${ }^{4}$ and \\ Sharmin Chowdhury ${ }^{2}$
}

\begin{abstract}
Background: Studying the characteristics of Aedes mosquito habitats is essential to control the mosquito population. The objective of this study was to identify the breeding sites of Aedes larvae and their distribution in Chattogram, Bangladesh. We conducted an entomological survey in 12 different sub-districts (Thana) under Chattogram City, during the late monsoon (August to November) 2019. The presence of different wet containers along with their characteristics and immature mosquitoes was recorded in field survey data form. Larvae and/or pupae were collected and brought to the laboratory for identification.
\end{abstract}

Results: Different indices like house index, container index, and the Breteau index were estimated. The multiple logistic regression analysis was applied to identify habitats that were more likely to be positive for Aedes larvae/ pupae. A total of 704 wet containers of 37 different types from 216 properties were examined, where 52 (7.39\%) were positive for Aedes larvae or pupae. Tire, plastic buckets, plastic drums, and coconut shells were the most prevalent container types. The plastic group possessed the highest container productivity (50\%) whereas the vehicle and machinery group was found as most efficient (1.83) in terms of immature Aedes production. Among the total positive properties, $8 \%$ were infested with Aedes aegypti, 2\% with Aedes albopictus, and 1\% contained both species Ae. aegypti and A. albopictus. The overall house index was 17.35\%, the container index was 7\%, and the Breteau index was 24.49. Containers in multistoried houses had significantly lower positivity compared to independent houses. Binary logistic regression represented that containers having shade were 6.7 times more likely to be positive than the containers without shade $(p<0.01)$.

Conclusions: These findings might assist the authorities to identify the properties, containers, and geographical areas with different degrees of risk for mosquito control interventions to prevent dengue and other Aedes-borne disease transmissions.

Keywords: Entomological survey, Aedes mosquito, Dengue transmission, Breeding sites, Wet container, Vectorborne disease, Stegomyia indices, Vector control

\footnotetext{
* Correspondence: sahid.dvm@gmail.com

'One Health Center for Research and Action, Akbarshah, Chattogram 4207,

Bangladesh

${ }^{2}$ One Health Institute, Chattogram Veterinary and Animal Sciences University,

Khulshi, Chattogram 4225, Bangladesh

Full list of author information is available at the end of the article
}

\section{Springer Open}

(c) The Author(s). 2021 Open Access This article is licensed under a Creative Commons Attribution 4.0 International License, which permits use, sharing, adaptation, distribution and reproduction in any medium or format, as long as you give appropriate credit to the original author(s) and the source, provide a link to the Creative Commons licence, and indicate if changes were made. The images or other third party material in this article are included in the article's Creative Commons licence, unless indicated otherwise in a credit line to the material. If material is not included in the article's Creative Commons licence and your intended use is not permitted by statutory regulation or exceeds the permitted use, you will need to obtain permission directly from the copyright holder. To view a copy of this licence, visit http://creativecommons.org/licenses/by/4.0/. 


\section{Background}

Aedes mosquitoes (Diptera: Culicidae) are a highly efficient vector of various arboviruses, including dengue, chikungunya, and Zika around the globe. Dengue fever is an important mosquito-borne disease (MBD) that poses a risk for more than 128 countries globally [1]. Aedes aegypti is the primary vector of the dengue virus (DENV) found in urban areas due to its anthropophilic blood-feeding behavior. Aedes albopictus belongs to the same subgenus (Stegomyia) considered as a secondary vector of DENV. They are primarily found in rural areas and peridomestic sites of urban areas like parks and green corridors interspersing housing estates. Both of these species were first recorded in Bangladesh in 1952 [2]. Since 2000, dengue fever (DF) cases have been reported every year in all major cities in Bangladesh [3]. The outbreak of chikungunya fever took place in 2008, and the Zika virus was also introduced in the country in 2016 [4, 5]. During 2019, Bangladesh recorded its largest dengue virus outbreak with 101,354 cases, more than double the cases in the last 20 years [6]. The Aedes spp. mostly breed in artificial water-holding containers but have been reported in natural containers as well [7]. Vector control remains the center of dengue prevention options, which can be done by limiting the transmission potential by reducing the emergence of adult mosquitoes. This could be achieved by targeting the aquatic habitats of the immature stages of Ae. aegypti through source reduction or biological and/or biocidal treatment $[8,9]$. The productivity of a container type depends on a range of factors, such as size and shape, the purpose of use, their locations, method of filling (passively/actively), the material of the container (plastic, metal, cement/clay, etc.), temperature, availability of food, and competition among co-species $[10,11]$.

Various entomological indices are used to measure dengue vector infestation in and around infrastructures, such as homes and buildings [12]. Examples of such indices are the different Stegomyia indices-house index (HI, the proportion of Aedes positive houses) and container index $(\mathrm{CI}$, the proportion of Aedes positive containers), and the Breteau index (BI, the number of Aedes positive containers per 100 houses) $[13,14]$. There is a lack of a sensitive vector surveillance tool to estimate the vector density in the outbreak areas. Therefore, the vector abundances for both Ae. aegypti and Ae. albopictus are still expressed as house index, Breteau index, and container index.

A few studies on Aedes mosquito abundance and breeding preference were conducted in the capital city Dhaka, Bangladesh. However, data on other big cities like Chattogram, the 2nd popular city in the country, are still absent. Therefore, during the late monsoon (August to November) of 2019, we conducted a comprehensive entomological survey in Chattogram. The expansion of residential areas to natural ecosystems, continuous changes in biodiversity, and increasing industrial areas in Chattogram promote the human-vector contact and the transmission of arboviruses to humans [15]. The objective was to identify the breeding sites of Aedes larvae and their distribution in Chattogram metropolitan area.

\section{Methods}

This entomological survey was conducted in late monsoon in 2019 between August and November, when dengue incidence was high in the study area and throughout Bangladesh [6]. The study location was Chattogram City of Bangladesh. Chattogram is the second largest city of Bangladesh and an area poorly studied in terms of mosquito surveys. A total of 12 sub-districts (Thana) under the Chattogram City Corporation (CCC) area were chosen for this survey (Fig. 1). A Thana is defined as the small administrative boundaries within the metropolitan area.

\subsection{Entomological survey}

An entomological study for DENV was designed to detect immature stages of the Aedes aegypti (L.) (Diptera: Culicidae). Our survey targeted all groups of juveniles (1st-4th instar larvae and pupae) by inspecting all accessible water-holding containers in public and private areas to identify the most productive and efficient container types of these species. The wet container is defined as any container with stagnant water at the time of the survey. Samples were taken by pipetting, dipping, or netting [16] in small plastic jars with water. Each sample jar was labeled with the unique identification number, date, location, and number of collected larvae/pupae. Breeding habitats of the collected mosquito species were recorded in a pre-defined survey data sheet during the sample collection (Appendix 1). Different indices were calculated to document the primary breeding source and density of the Aedes mosquito. A container was recorded as positive for Aedes if one or more juvenile Ae. aegypti or Ae. albopictus was found in the given type of container and was distinguished from those with no juveniles (negative). During the survey period, the ambient temperature of the area ranged from 21 to $32{ }^{\circ} \mathrm{C}$. The rainfall was $435.6 \mathrm{~mm}$ in August, and then gradually decreased to $18.9 \mathrm{~mm}$ in November 2019 [17].

\subsection{Selection of properties}

A total of 18 different locations were surveyed, including government-owned properties. The properties were purposely selected from each Thana and were categorized into nine classes, depending on the possession of living properties, working stations, and other public gathering places, as shown in Table 1. Moreover, all properties were broadly divided into two classes-residential and 


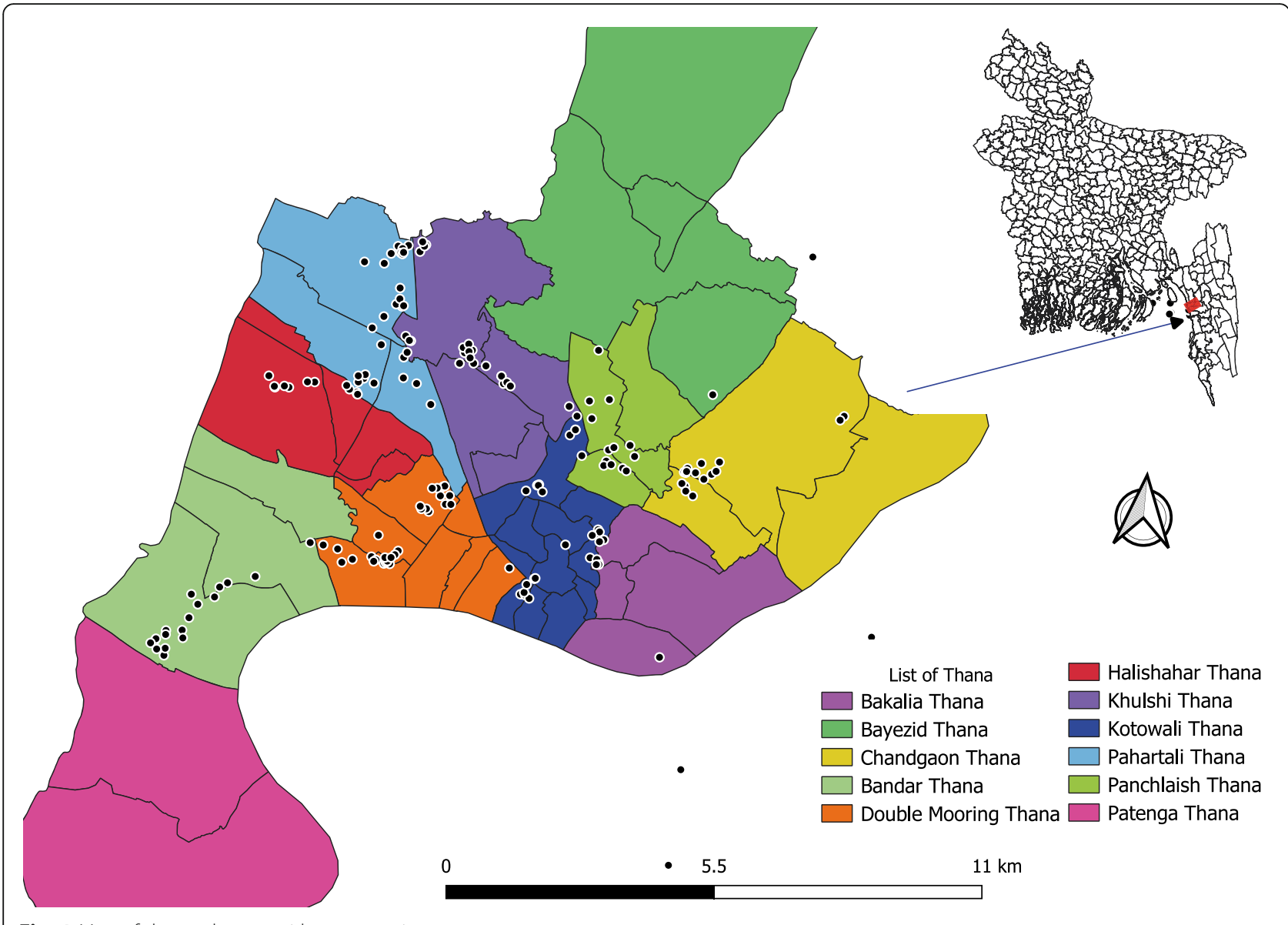

Fig. 1 Map of the study area with survey points

Table 1 Number and type of properties surveyed in each Thana

\begin{tabular}{|c|c|c|}
\hline Types of properties & Number of properties from each Thana & Definition of different properties \\
\hline Independent house & 4 & $\begin{array}{l}\text { These were brick-built single-family homes, either single floor or duplex } \\
\text { with the surrounding garden. }\end{array}$ \\
\hline Multistoried house & 4 & $\begin{array}{l}\text { These were brick-built apartment houses having two or more floors. } \\
\text { More than one family lives in these houses. }\end{array}$ \\
\hline Slum & 4 & $\begin{array}{l}\text { Slum houses are usually made of bamboo and tin, or even mud walls. } \\
\text { These are inadequate infrastructure with congested tenements. }\end{array}$ \\
\hline Construction site & 1 & Independent or multi-storied buildings in the construction phase \\
\hline Police station & 1 & $\begin{array}{l}\text { The local police station area in each Thana. This is usually an area of a } \\
\text { single building with an open place and garden. }\end{array}$ \\
\hline Educational institution & 1 & $\begin{array}{l}\text { Any properties like schools, colleges, universities, or others used for } \\
\text { educational purposes. It comprises either small or big areas. }\end{array}$ \\
\hline Hospital & 1 & Government or private hospitals, clinics, diagnostic centers \\
\hline Open place/park & 1 & $\begin{array}{l}\text { Any open spaces like parks, roadside places, or playgrounds without } \\
\text { any establishment }\end{array}$ \\
\hline Bus stand/garage & 1 & Small and large bus stands, garages, or fuel station \\
\hline
\end{tabular}


non-residential. All types of households were included under residential areas whereas other properties considered as non-residential areas.

\subsection{Classification of containers found as larval development sites}

The containers were divided into two broad groups based on their purposes: controllable and disposable ones. Controllable containers were household containers that could be manipulated by man to avoid mosquito larval breeding. It included concrete tanks, metal drums, flower pots, aluminum tanks, small buckets, and other plastic containers used to carry or store water. Disposable containers were those that are not used in households, are abandoned or stored in backyards having the potential as breeding sites in the rainy season. Examples of disposable containers include tires, cans, and tubs.

\subsection{Identification of mosquitoes}

After collection, the larvae and/or pupae were brought to the pathology and parasitology laboratory of Chattogram Veterinary and Animal Sciences University, located within the city of Chattogram. Larvae were identified under microscopes in the laboratory. Pupae and the rest of the larvae were reared in rearing trays for the identification of adult mosquitos. Species identification was completed using standard identification keys as described in a literature [18]. The laboratory findings were recorded in the corresponding survey sheet.

\subsection{Determine the key containers}

All wet containers were divided into six categories based on the materials they were composed of or the purposes they served. The categories were plastic receptacles, tin and metal receptacles, cement and clay receptacles, natural receptacles, vehicle and machinery parts, and other receptacles. The role of these container categories regarding the production of Aedes mosquito was estimated by the value of container productivity and container efficiency [19]

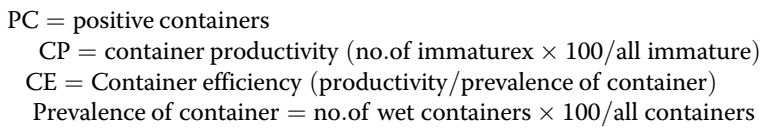

\subsection{Estimate different indices}

The number of different wet containers, the percentage of positive containers, and the percentage of Aedes larvae in each container category were calculated to determine the various Stegomyia indices as follows [16]:

Container index: the percentage of water-holding containers infested with larvae and/or pupae
House index: the percentage of house infested with larvae and/or pupae

Breteau index: the number of positive containers per 100 houses inspected.

\subsection{Statistical analysis}

Zero-inflated negative binomial regression analysis was performed to find the factors associated with the number of immature Aedes positive mosquito per container. The binary logistic regression was used to find the odds of the background characteristics causing the containers to be Aedes positive. The exponential of the logistic regression parameter was the odds of the category of the background characteristics being Aedes positive of water-holding containers. The exponential of zero-inflated negative binomial regression was the ratio of the average number of immature Aedes positive mosquitoes among the groups of background characteristics. Data analysis was conducted in $\mathrm{R}$ version 3.5.2, and the binary logistic regression model was performed in SPSS version 25.

\section{Results}

A total of 704 wet containers of 37 varieties were identified around 216 surveyed properties, with a mean of 3.3 containers per property. Of these, 204 (29\%) were controllable, and $500(71 \%)$ were disposable containers. More containers were identified on privately owned properties $(N=531,75 \%)$ than government $(N=173$, 25\%) owned properties. We collected 573 Aedes juveniles, including 101 pupae. The number of Ae. aegypti $(n=371)$ was higher than the number of Ae. albopictus (202). We calculated the house index as $17.35 \%$, container index 7\%, and the Breteau index 24.49. The distribution of wet containers found in the entomological survey is summarized in Table 2.

\subsection{Distribution of positive containers and juvenile Aedes} spp.

Among the total of 704 wet containers, 49 (6.9\%) were positive for immature Aedes mosquitoes. Among positive containers, $31 \% \quad(n=15)$ were controllable (plastic bucket, plastic drums, plastic bag, and earthen jar), and 69\% $(n=34)$ were disposable (containers like tires, coconut shell, cock sheet, mineral water jar, and bamboo hole). A total of $32.65 \%(n=16)$ positive containers were found in government-owned properties, and the rest $67.35 \%(n=33)$ were in private properties. Among positives, $96 \%(n=47)$ of containers was under shades, and 39\% $(n=19)$ had vegetation in and around the container. Independent houses possessed maximum numbers of positive containers amounting 33\% $(n=16)$. Other than living places, different open places or parks contained $13 \%(n=6)$, and educational institutions had $10 \%(n=5)$ of the positive containers. 
Table 2 General distribution of the background characteristics of wet containers in Chattogram, Bangladesh

\begin{tabular}{|c|c|c|c|c|}
\hline Variables & Category & Frequency & Percentage & Aedes-positive container (\%) \\
\hline \multirow[t]{2}{*}{ Container function } & Controllable & 204 & 29 & $15(31)$ \\
\hline & Deposable & 500 & 71 & $34(69)$ \\
\hline \multirow[t]{2}{*}{ Ownership } & Government & 173 & 25 & $16(32.65)$ \\
\hline & Private & 531 & 75 & $33(67.35)$ \\
\hline \multirow[t]{2}{*}{ Vegetation } & No & 401 & 58 & $30(61)$ \\
\hline & Yes & 297 & 42 & $19(39)$ \\
\hline \multirow[t]{2}{*}{ Shade } & No & 129 & 18 & $2(4)$ \\
\hline & Yes & 572 & 82 & $47(96)$ \\
\hline \multirow[t]{2}{*}{ Residence type } & Residential area & 432 & 61 & $30(61)$ \\
\hline & Non-residential area & 272 & 39 & $19(39)$ \\
\hline \multirow[t]{9}{*}{ Property category } & Independent house & 157 & 22 & $16(33)$ \\
\hline & Multistoried house & 141 & 20 & $4(8)$ \\
\hline & Slum & 134 & 19 & $10(20)$ \\
\hline & Police station & 67 & 10 & $3(6)$ \\
\hline & Hospital & 48 & 7 & $0(0)$ \\
\hline & Bus stand/garage & 51 & 7 & $4(8)$ \\
\hline & Educational institutions & 37 & 5 & $5(10)$ \\
\hline & Open place/park & 49 & 7 & $6(13)$ \\
\hline & Construction site & 20 & 3 & $1(2)$ \\
\hline \multirow[t]{6}{*}{ Container category } & Plastic reservoir & 215 & 31 & $16(33)$ \\
\hline & Metal/tin/aluminum reservoir & 47 & 7 & $2(4)$ \\
\hline & Cement/clay/ceramic reservoir & 86 & 12 & $4(8)$ \\
\hline & Natural and plant material & 181 & 26 & $13(27)$ \\
\hline & Vehicles and machinery items & 116 & 16 & $12(24)$ \\
\hline & Others & 59 & 8 & $2(4)$ \\
\hline \multirow[t]{12}{*}{ Geographic location } & Khulshi & 109 & 15 & $8(16)$ \\
\hline & Pahartali & 70 & 10 & $13(27)$ \\
\hline & Bakalia & 41 & 6 & $2(4)$ \\
\hline & Kotowali & 62 & 9 & $1(2)$ \\
\hline & Panchlaish & 52 & 7 & $11(23)$ \\
\hline & Double Mooring & 55 & 8 & $5(10)$ \\
\hline & Halishahar & 22 & 3 & $3(6)$ \\
\hline & Bandar & 43 & 6 & $1(2)$ \\
\hline & Chandgawn & 91 & 13 & $1(2)$ \\
\hline & EPZ & 51 & 7 & $1(2)$ \\
\hline & Akbarshah & 69 & 10 & $3(6)$ \\
\hline & Bayezid & 39 & 6 & $0(0)$ \\
\hline
\end{tabular}

The highest positive containers were recorded in Panchlaish followed by Pahartali and Halishahar Thana. No positive containers were found in Bayezid Thana. Figure 2 shows the distribution of positive containers in different Thanas.

A total of 216 properties from 12 Thanas under the Chattogram City Corporation (CCC) area were visited, where $16.2 \%(n=35)$ properties were found positive for immature Aedes mosquito. Among the total positive properties, $7.2 \%(n=28)$ were infested with Aedes aegypti and $2.3 \%(n=9)$ were Aedes albopictus. Moreover, Ae. aegypti co-existed with A. albopictus in $1.3 \%(n=5)$ properties. 


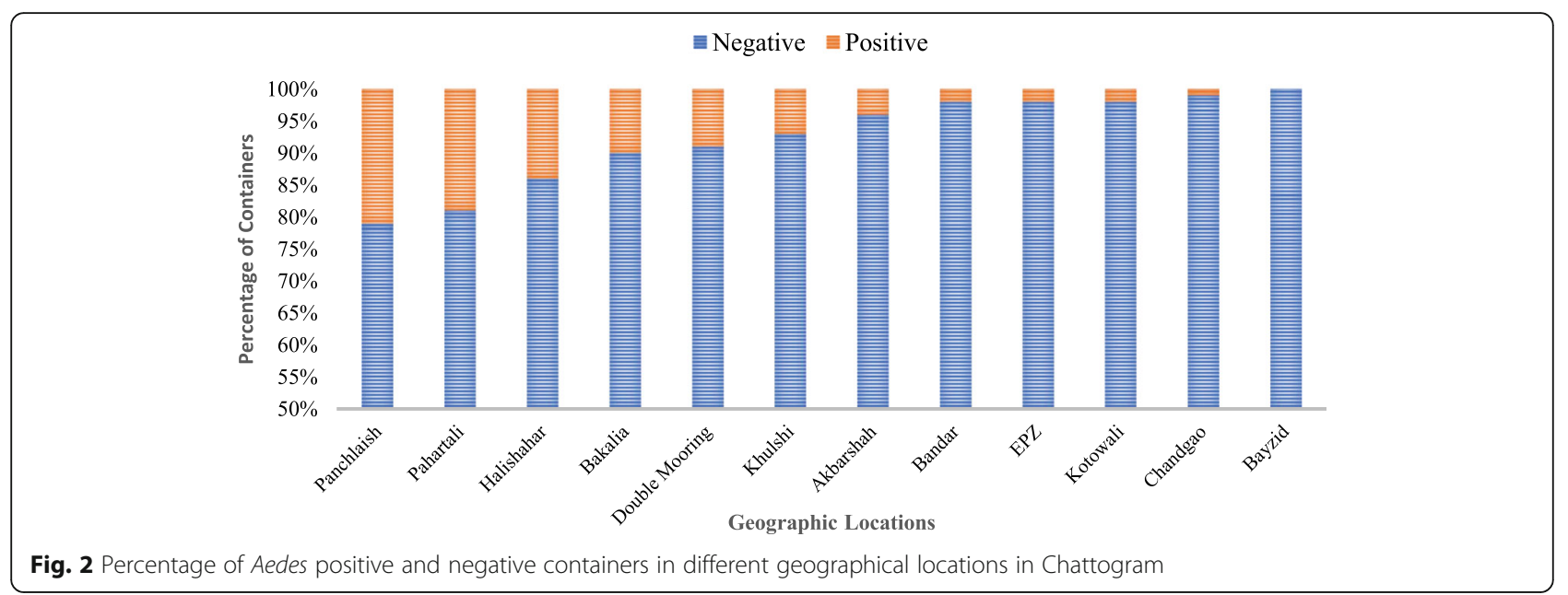

Among individual containers, tires $16.33 \%(n=8)$ were revealed as the most productive container for the Aedes larval breeding, followed by plastic buckets $14.29 \%(n=$ 7), coconut shells $12.24 \%(n=6)$, plastic drums $12.24 \%$ $(n=6)$, and flower tub and tray $8.16 \%(n=4)$ (see Fig. 3).

\subsection{Determining the key containers}

According to immature Aedes production in different container categories, the plastic container had the most abundantly (33\%) found positive and possessed the highest container productivity (50). Vehicle and machinery group was the most efficient (1.83) and 2nd most productive (30) group. The natural group contained 27\% positive containers with container productivity of 11 . So, these three container categories could be considered as necessary for Aedes spp. mosquito breeding. The role of all container categories is shown in Table 3.

Zero-inflated negative binomial regression (Table 4) revealed that the number of immature Aedes mosquito produced per container had a significant association with the property category and shade $(p<0.01)$. Binary logistic regression (Table 5) elucidated that containers having shade had 6.7 times more likely to be positive than the containers without shade $(p<0.05)$. Containers in multi-storied houses had significantly lower positivity in comparison to independent houses. Besides, Kotowali and Bandar Thana produced significantly lower number of positive containers $(p<0.05)$ as their odds found below one.

\section{Discussion}

We inspected a broad spectrum of wet containers from different properties in the second most populated city of Bangladesh and identified Aedes larvae and/or pupae. The total number of Ae. aegypti larvae and/or pupae was higher than the number of Ae. Albopictus, and the record was consistent with previous studies [20, 21]. Opposite results were found in Malaysia that $77 \%$ of breeding containers were positive for Aedes albopictus and $23 \%$ for Aedes aegypti [22]. As the survey was conducted in city areas only, the breeding sites of Ae. albopictus were reached partially which might be a reason

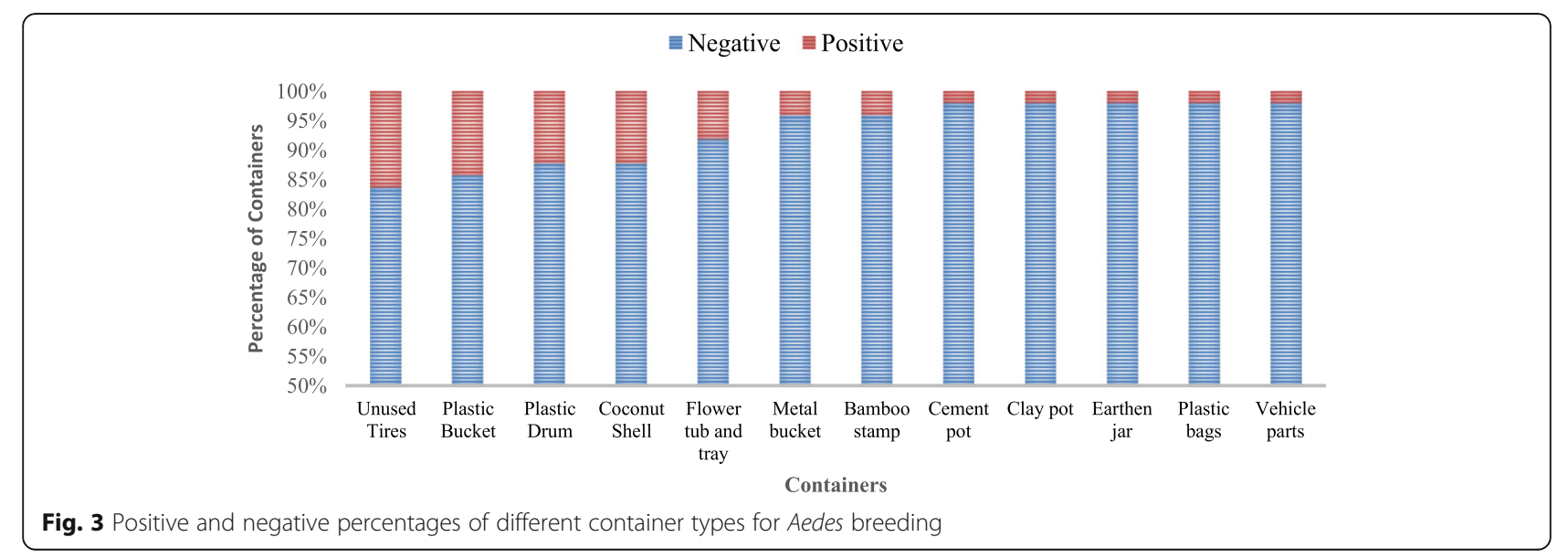


Table 3 The efficiency of different container categories for the production of Aedes larvae

\begin{tabular}{|c|c|c|c|c|c|c|}
\hline $\begin{array}{l}\text { Container } \\
\text { category }\end{array}$ & Containers & $\begin{array}{l}\text { Frequency } \\
(\%)\end{array}$ & $\begin{array}{l}\text { Positive } \\
\text { containers (\%) }\end{array}$ & $\begin{array}{l}\text { Immature } \\
\text { Aedes }\end{array}$ & $\mathrm{CP}$ & CE \\
\hline Plastic receptacles & $\begin{array}{l}\text { Plastic bucket, plastic drum, mineral water jar, Dahi pot, plastic bag, } \\
\text { water tank, plastic bottle, plastic mug }\end{array}$ & $215(31)$ & $16(33)$ & 4818 & 50 & 1.62 \\
\hline $\begin{array}{l}\text { Tin and metal } \\
\text { receptacles }\end{array}$ & Metal/tin can, metal bucket, metal drum, metal pan, aluminum pot & $47(7)$ & $2(4)$ & 345 & 3.5 & 0.53 \\
\hline $\begin{array}{l}\text { Cement and clay } \\
\text { receptacles }\end{array}$ & $\begin{array}{l}\text { Cement pot, clay pot, animal bowl, glass bottle, ceramic pot, melamine } \\
\text { bowl, earthen jar }\end{array}$ & $86(12)$ & $4(8)$ & 295 & 3 & 0.25 \\
\hline Natural receptacles & $\begin{array}{l}\text { Coconut shell, mud hole, bamboo stamp, plant axil, tree hole, flooded } \\
\text { floor, money plan tub, flower tub, and tray. }\end{array}$ & $181(25)$ & $13(27)$ & 1086 & 11 & 0.43 \\
\hline $\begin{array}{l}\text { Vehicle and } \\
\text { machinery parts }\end{array}$ & $\begin{array}{l}\text { Vehicle parts, tires, battery, water motor, cock sheet, air cooler, musical } \\
\text { instrument, cement mixture }\end{array}$ & $116(17)$ & $12(24)$ & 2934 & 30 & 1.83 \\
\hline Others receptacles & Unused sheet, plastic sheet, discarded food wrapper, broken toilet parts & $59(8)$ & $2(4)$ & 275 & 3 & 0.34 \\
\hline
\end{tabular}

$\mathrm{CP}=$ container productivity (no. of immature $\times 100 /$ all immature)

$\mathrm{CE}=$ container efficiency (productivity/prevalence of container)

Prevalence of container $=$ no. of wet containers $\times 100 /$ all containers

for the lower count of Ae. albopictus. The mean number of wet containers per property was 3.3 in our study, which is comparatively lower than the mean numbers of two previous studies 4.20 found in Dhaka [7] and 7.9 found in Southern Mexico [23]. A possibility could be because people were more aware due to the devastating dengue epidemic in 2019.

The overall house index (HI), container index (CI), and Breteau index (BI) were calculated high which is supported by a similar study conducted in Dhaka earlier stating the overall HI 14.2\%, BI 24.65, and CI 5.9\% [7]. All of the indexes showed a high level of risk for dengue transmission. A survey in Nepal found higher CI in the post-monsoon period than monsoon [24]. A recent study in Malaysia showed maximum $\mathrm{HI}=13.33 \%, \mathrm{BI}=13$, and $\mathrm{CI}=19.05 \%$ [22]. In a literature [13], it has been criticized that these indices are of operational value and are of limited use in assessing the transmission risk. However, these indexes are indicative of the global transmission risk at the community level.

The biggest portion of Aedes larvae containing waterholding containers was under the group of disposable containers. The estimated larval productions in disposable containers in other settings were $70 \%$ and $55.4 \%$
[23]. This indicates that the proper and regular disposal of unused containers will make a great contribution to vector control programs. The common containers for Aedes breeding were plastic containers (30\%) in Kuala Lumpur, Malaysia [22]. As individual container types, we found the contribution of unused tires as the highest for Aedes larval breeding along with other key containersplastic buckets, plastic drums, coconut shells, and flower tubes and trays. Our results are consistent with the findings of two previous studies in Dhaka, Bangladesh, conducted during 2011-2013 [25, 26]. A study in Nepal stated discarded tires as the preferable wet containers [24]. Another study revealed flower pots as the principal types of containers with Ae. aegypti larvae [27].

Figure 2 shows that Panchlaish, Pahartali, and Halishahar Thana contained maximum positive containers. These Thanas possess many residential areas residing a huge population of the city. And many parts under these areas become flooded after a rain due to poor sewerage system, whereas Bayezid Thana had no positive containers as this area is an intensive industrial hub with limited access and having minimum residential properties. Within a community, not all houses have the same potential for larval breeding. The identification of those houses that are likely

Table 4 Zero-inflated negative binomial regression of Aedes positive with the background characteristics of water-holding containers

\begin{tabular}{lllllc}
\hline Predictors & Estimate (coefficient) & Standard error & Odds ratio & \multicolumn{2}{l}{ Confidence interval at 95\% level } \\
\hline Vegetation (yes) & 0.2212 & 0.2506 & 1.247573 & 0.7633177 & 2.0389762 \\
Function (disposable) & -0.06422 & 0.39760 & 0.937799 & 0.4302001 & 2.0443182 \\
Container category & 0.13840 & 0.10919 & 1.148435 & 0.9271832 & 1.4224860 \\
Property category (Mult. house) & 1.49129 & 0.64479 & 4.442823 & 1.255475 & $15.721946 * 6^{* *}$ \\
Location (Kotowali) & 2.02446 & 1.15621 & 7.572021 & 0.7853205 & $73.0097627^{*}$ \\
Property type (private) & -0.02158 & 0.57382 & 0.978651 & 0.3178280 & 3.0134419 \\
Shade (yes) & -1.87277 & 0.77507 & 0.153697 & 0.0336452 & $0.7021209^{* *}$ \\
\hline
\end{tabular}

Significance codes: ${ }^{*} 0.01,{ }^{*} 0.05$ 
Table 5 Binary logistic regression to identify factors associated with the presence of Aedes sp. larvae and/or pupae

\begin{tabular}{|c|c|c|c|c|c|}
\hline \multirow{2}{*}{$\begin{array}{l}\text { Predictors } \\
\text { Function (controllable) }\end{array}$} & \multirow[t]{2}{*}{ Estimated } & \multirow[t]{2}{*}{ Standard error } & \multirow{2}{*}{$\frac{\text { Odds ratio }}{1}$} & \multicolumn{2}{|c|}{ Confidence interval at $95 \%$} \\
\hline & & & & & \\
\hline Function (disposable) & 0.091 & 0.431 & 1.095 & 0.471 & 2.547 \\
\hline Vegetation (no) & & & 1 & & \\
\hline Vegetation (yes) & 0.685 & 0.42 & 1.983 & 0.87 & 4.521 \\
\hline Property type (Gov.) & & & 1 & & \\
\hline Property type (private) & 0.15 & 0.695 & 1.162 & 0.297 & 4.539 \\
\hline Shade (no) & & & 1 & & \\
\hline Shade (yes) & 1.902 & 0.808 & 6.701 & 1.374 & $32.675^{*}$ \\
\hline Property category (independent house) & & & 1 & & \\
\hline Property category (multistoried house) & -1.246 & 0.605 & 0.288 & 0.088 & $0.942^{*}$ \\
\hline Property category (slum) & -0.381 & 0.526 & 0.683 & 0.244 & 1.915 \\
\hline Property category (police stations) & 0.358 & 1.104 & 1.431 & 0.164 & 12.461 \\
\hline Property category (hospitals) & -19.407 & 7369.331 & 0 & 0 & . \\
\hline Property category (bus stations) & 0.03 & 0.905 & 1.031 & 0.175 & 6.07 \\
\hline Property category (educational institutions) & 0.313 & 1.033 & 1.368 & 0.181 & 10.357 \\
\hline Property category (open place) & 0.114 & 0.819 & 1.12 & 0.225 & 5.575 \\
\hline Property category (construction site) & -0.07 & 1.26 & 0.933 & 0.079 & 11.018 \\
\hline Thana (Khulshi) & & & 1 & & * \\
\hline Thana (Pahartali) & 0.421 & 0.787 & 1.524 & 0.326 & 7.127 \\
\hline Thana (Bakalia) & -1.27 & 0.931 & 0.281 & 0.045 & 1.74 \\
\hline Thana (Kotowali) & -2.538 & 1.176 & 0.079 & 0.008 & $0.793^{*}$ \\
\hline Thana (Panchlaish) & 0.285 & 0.657 & 1.33 & 0.367 & 4.823 \\
\hline Thana (Double Mooring) & -0.925 & 0.745 & 0.397 & 0.092 & 1.708 \\
\hline Thana (Halishahar) & -0.098 & 0.875 & 0.907 & 0.163 & 5.041 \\
\hline Thana (Bandar) & -2.45 & 1.182 & 0.086 & 0.008 & $0.876^{*}$ \\
\hline Thana (Chandgaon) & -1.74 & 1.185 & 0.175 & 0.017 & 1.791 \\
\hline Thana (EPZ) & -2.281 & 1.207 & 0.102 & 0.01 & 1.089 \\
\hline Thana (AkbarShah) & -1.406 & 0.826 & 0.245 & 0.049 & 1.237 \\
\hline Thana (Patenga) & -20.22 & 6992.331 & 0 & 0 & . \\
\hline Container category (plastic) & & & 1 & & \\
\hline Container category (metal) & -0.547 & 0.939 & 0.579 & 0.092 & 3.649 \\
\hline Container category (cement) & -0.439 & 0.682 & 0.644 & 0.169 & 2.452 \\
\hline Container category (natural) & -0.941 & 0.587 & 0.39 & 0.123 & 1.234 \\
\hline Container category (vehicles) & 0.334 & 0.533 & 1.397 & 0.491 & 3.973 \\
\hline Container category (others) & -1.724 & 0.851 & 0.178 & 0.034 & $0.945^{*}$ \\
\hline
\end{tabular}

Significance codes: ${ }^{*} 0.05$

to have high larval production is important to better direct control activities. Independent households having disposable wet containers in shaded outdoor premises were significantly associated with the infestation of Aedes larvae [7]. Notably, the survey found more juveniles in containers of private properties compared to those on government properties, similar to the findings of a previous study which showed more containers on privately owned properties than in government properties [28]; private properties also have 1.7 times greater odds $(95 \% \mathrm{CI}=1.1$ 2.5) of being infested compared with containers on government properties [29]. We observed that Ae. aegypti and $A$. albopictus co-existed in different properties supported by an earlier study in Jinghong City, China [30]. It suggested that both species should be managed during the dengue epidemic season.

This study revealed that independent houses were the most infested with containers possessing Aedes larvae, 
followed by slums and open places/parks. The findings are concordant with the earlier studies conducted in other cities of the country which stated that the household positivity rate was the highest in independent houses $(18.6 \%)$, followed by slum houses $(14.3 \%)$, semipermanent houses (12.9\%), and multi-storied houses (12.8\%) [7]. A study in Japan during a dengue epidemic showed that more than $80 \%$ of dengue patients visited a city park where Ae. albopictus was present [31]. It reveals that positive containers in open places/parks might impose risk of the dengue fever for city dwellers.

The observations or experimental units were the water-holding containers spread over the different locations in Chittagong city. We analyzed the count data of the number of immature Aedes-positive larvae and/or pupae per container, with access zero accounts for nonAedes, by a statistical model. A multiple regression model was applied using the predictors of background characteristics (container function, ownership, vegetation, shade, property category, container category, and geographic location) of water-holding containers [28]. To deal with access zero, we considered the zeroinflated Poisson regression model [32] and zero-inflated negative binomial regression model [33] to find the association between the number of immature Aedes-positive mosquitoes per container and the background characteristics of the water-holding containers. Both of the considered models are modifications of the count data regression model. The Akaike Information Criteria (AIC) value was calculated to find the improved model between the two $[34,35]$. The zero-inflated negative binomial regression model (543.82) has less AIC value than the zero-inflated Poisson regression model (693.16). Hence, the zero-inflated negative binomial regression model better fit our data.

Containers located under any shelter that did not allow rain water to get into are considered as containers with shade. We observed that wet containers under shade were more likely to have Ae. aegypti, unlike previous findings where more larvae and pupae were detected in containers without shade than the containers located in areas with full shades [26]. The opposite findings may have been due to the classification of containers as partially shaded and fully shaded by the researchers. However, a recent study in Dhaka found that containers with partial shades produced 4.6 times more pupae than without shade [25]. Containers located outdoors and proximal to vegetation were significant for producing larvae [29]. We also found odds greater than one for containers possessing vegetation. Vegetation in and around containers might enhance mosquito breeding by facilitating resting sites for gravid females to lay eggs and important sugar-feeding resources for larvae [36]. The larval production of any species of mosquitoes is significantly affected by vegetation near the containers [26].

Probability sampling was not performed in this study which could lead to a selection bias in the result. We examined the surroundings outside of the properties, excluding the inside. The survey covered different residential and non-residential properties like open places/parks, educational institutes, hospitals but devoid of shopping/open market areas, other office buildings, and religious buildings. The total number of containers was also limited to some extent. A few recent studies used different container parameters like size or volume of the container, exposure to sunlight, cover status, and filling methods for evaluating container productivity. We considered exposure to sunlight/shade and vegetation status, function of composing materials of containers. Previous studies suggested that the extensive vector control program by reducing breeding sites could maintain a low Aedes house index [27]. Therefore, the weekly cleaning of the water-holding containers could effectively control larval production [21].

\section{Conclusions}

The study detected Ae aegypti in 8\%, Ae albopictus in $2 \%$ of the properties, and the co-existence of both Ae. aegypti and $A$. albopictus in $1 \%$ of properties, which posed high risks of dengue transmission. The presence of shades on the breeding sites could significantly increase the risk of having Aedes spp. mosquito larvae. Plastic containers were the most abundant and productive containers while the vehicle and machinery category was found as the most efficient container group for $\mathrm{Ae}$ des mosquito breeding. We recommend vector control through regular inspection and destruction of potential container types to prevent the dengue outbreak.

\section{Abbreviations}

Ae: Aedes; /: Divide; etc.: Etcetera; <: Less than; $x$ : Multiply; $n$ : Number R: Analytic software; 2nd: Second; spp.: Species; SPSS: Statistical packages for social sciences

\section{Supplementary Information}

The online version contains supplementary material available at https://doi. org/10.1186/s43088-021-00122-x.

\section{Additional file 1: Appendix 1. Survey sheet}

\section{Acknowledgements}

We would like to thank the residents and the police department of Chattogram City for allowing us in their premises. We acknowledge the sincere guidance from Mrs. Entazar Ferdous, district entomologist, Chattogram. We are also thankful to all the research ambassadors who worked under the "One Health Center for Research and Action" especially Imran Khan, Tishita Sen Ape, Md. Mynul Islam, and Md. Ibnul Bakhtier for their assistance during the field work. 


\section{Authors' contributions}

Conceptualization: MSR, NH. Methodology: MSR, NH. Field-work and data curation: MSR, ST, NMS. Laboratory work: MSR. Data analysis: MSR, OMF, SC. Writing-original draft: MSR, MOF, ST, NMS. Writing —review and editing: SC, MSR, NH. The authors read and approved the final manuscript.

\section{Funding}

This research did not receive any specific grant from funding agencies in the public, commercial, or not-for-profit sectors.

\section{Availability of data and materials}

Data and supporting materials will be available from the authors upon reasonable request.

\section{Declarations}

\section{Ethics approval and consent to participate}

This study was carried out in accordance with the recommendations of the Chattogram Veterinary and Animal Sciences University's Ethics Committee. However, this study was waived for written approval and consent as it did not involve human participants, human data or human tissues.

\section{Consent for publication}

Not applicable

\section{Competing interests}

The authors declare that they have no competing interests.

\section{Author details}

'One Health Center for Research and Action, Akbarshah, Chattogram 4207, Bangladesh. ${ }^{2}$ One Health Institute, Chattogram Veterinary and Animal Sciences University, Khulshi, Chattogram 4225, Bangladesh. ${ }^{3}$ Department of Statistics, Noakhali Science and Technology University, Noakhali, Bangladesh. ${ }^{4}$ The Royal Veterinary College, University of London, London, UK.

\section{Received: 4 February 2021 Accepted: 3 May 2021}

\section{Published online: 13 May 2021}

\section{References}

1. WHO (2017) Dengue and severe dengue. Updated Apr 2017. Im Internet www.who.int/mediacentre/factsheets/fs117/en

2. Asir-Ud-Din M (1952) Mosquitoes breeding in tree-holes and bamboo stumps in Dacca (East Pakistan). Pak J Health 2:110-112

3. Mahmood B, Mahmood S (2011) Emergence of dengue in Bangladesh a major international public health concern in recent years. J Environ Res Manag 2:35-41

4. Khatun S, Chakraborty A, Rahman M, Nasreen Banu N, Rahman MM, Hasan SMM, Luby SP, Gurley ES (2015) An outbreak of chikungunya in rural Bangladesh, 2011. PLoS Negl Trop Dis 9(7):e0003907. https://doi.org/10.13 71/journal.pntd.0003907

5. Salje H, Lessler J, Paul KK, Azman AS, Rahman MW, Rahman M, Cummings D, Gurley ES, Cauchemez S (2016) How social structures, space, and behaviors shape the spread of infectious diseases using chikungunya as a case study. Proc Natl Acad Sci 113(47):13420-13425. https://doi.org/10.1073/ pnas. 1611391113

6. Ahsan A, Haider N, Kock R, Benfield C (2020) Possible drivers of the 2019 dengue outbreak in Bangladesh: the need for a robust community-level surveillance system. J Med Entomol. https://doi.org/10.1093//me/tjaa150

7. Ferdousi F, Yoshimatsu S, Ma E et al (2015) Identification of essential containers for Aedes larvae breeding to control dengue in Dhaka, Bangladesh. Trop Med Health 43(4):253-264. https://doi.org/10.2149/tmh.2 015-16

8. Lin C-H, Schiøler KL, Ekstrøm CT, Konradsen F (2018) Location, seasonal, and functional characteristics of water holding containers with juvenile and pupal Aedes aegypti in Southern Taiwan: a cross-sectional study using hurdle model analyses. PLoS Negl Trop Dis 12(10):e0006882. https://doi. org/10.1371/journal.pntd.0006882

9. WHO (2014) Global strategy for dengue prevention and control 2012-2020. WHO, Geneva 2012. Assoc dengue symptoms with Haematol parameters Retrosp study 10 Hosp India
10. Strickman D, Kittayapong P (2003) Dengue and its vectors in Thailand: calculated transmission risk from total pupal counts of Aedes aegypti and association of wing-length measurements with aspects of the larval habitat. Am J Trop Med Hyg 68(2):209-217. https:/doi.org/10.4269/ajtmh.2003.68.209

11. Morrison AC, Gray K, Getis A, Astete H, Sihuincha M, Focks D, Watts D, Stancil JD, Olson JG, Blair P, Scott TW (2004) Temporal and geographic patterns of Aedes aegypti (Diptera: Culicidae) production in lquitos, Peru. J Med Entomol 41(6):1123-1142. https://doi.org/10.1603/0022-2585-41.6.1123

12. Bowman LR, Runge-Ranzinger S, McCall PJ (2014) Assessing the relationship between vector indices and dengue transmission: a systematic review of the evidence. PLoS Negl Trop Dis 8(5):e2848. https://doi.org/10.1371/journal. pntd. 0002848

13. Focks DA (2003) A review of entomological sampling methods and indicators for dengue vectors. World Health Organization, Geneva

14. Guo YH, Lai SJ, Liu XB et al (2016) Governmental supervision and rapid detection on dengue vectors: an important role for dengue control in China. Acta Trop 156:17-21. https://doi.org/10.1016/j.actatropica.2015.12.011

15. Ferro C, Las Salas J, González M et al (2015) Do some conditions contribute to the reemergence of the Venezuelan equine encephalitis virus in the Colombian Alta Guajira? Biomédica 35(1):62-72. https://doi.org/10.1590/ S0120-41572015000100009

16. WHO (2009) Dengue guidelines for diagnosis, treatment, prevention and control

17. Weather2visit (2020) Chittagong weather averages \& monthly temperatures | Bangladesh | Weather-2-Visit. https://www.weather2visit.com/asia/bangla desh/chittagong.htm. Accessed 26 Mar 2021

18. Rueda $L$ (2004) Pictorial keys for the identification of mosquitoes (Diptera: Culicidae) associated with dengue virus transmission

19. Hammond SN, Gordon AL, Del Lugo EC, et al. (2007) Characterization of Aedes aegypti (Diptera: Culcidae) production sites in Urban Nicaragua

20. Dhar-Chowdhury P, Haque CE, Lindsay R, Hossain S (2016) Socioeconomic and ecological factors influencing Aedes aegypti prevalence, abundance, and distribution in Dhaka, Bangladesh. Am J Trop Med Hyg 94(6):12231233. https://doi.org/10.4269/aitmh.15-0639

21. Arunachalam N, Tana S, Espino F, Kittayapong P, Abeyewickreme W, Wai KT, Tyagi BK, Kroeger A, Sommerfeld J, Petzold M (2010) Eco-bio-social determinants of dengue vector breeding: a multicountry study in urban and periurban Asia. Bull World Health Organ 88(3):173-184. https://doi.org/1 0.2471/BLT.09.067892

22. Amierul Fikri Mahmud M, Hatta Mutalip M, Aliza Lodz N et al (2018) Study on key Aedes spp breeding containers in dengue outbreak localities in Cheras district, Kuala Lumpur. Int J Mosq Res 5:23-30

23. Danis-Lozano R, Rodriguez MH, Hernández-Avila M (2002) Gender-related family head schooling and Aedes aegypti larval breeding risk in Southern Mexico. Salud Publica Mex 44(3):237-242. https://doi.org/10.1590/s0036-3 6342002000300007

24. WHO (2014) Dengue Bulletin. https://apps.who.int/iris/bitstream/handle/1 0665/204945/B5158.pdf;jsessionid=67D7917D78E52202605FA76C6368F083 ?sequence $=1$. Accessed 26 Dec 2020

25. Islam S, Haque CE, Hossain S, Rochon K (2019) Role of container type, behavioural, and ecological factors in Aedes pupal production in Dhaka, Bangladesh: an application of zero-inflated negative binomial model. Acta Trop 193:50-59. https://doi.org/10.1016/j.actatropica.2019.02.019

26. Paul KK, Dhar-Chowdhury P, Haque CE, al-Amin HM, Goswami DR, Kafi MAH, Drebot MA, Lindsay LR, Ahsan GU, Brooks WA (2018) Risk factors for the presence of dengue vector mosquitoes, and determinants of their prevalence and larval site selection in Dhaka, Bangladesh. PLoS One 13(6): e0199457. https://doi.org/10.1371/journal.pone.0199457

27. Egger J, Ooi E et al (2008) Reconstructing historical changes in the force of infection of dengue fever in Singapore: implications for surveillance and control. SciELO Public Heal:187-196

28. Lin CH, Schiøler KL, Ekstrøm CT, Konradsen F (2018) Location, seasonal, and functional characteristics of water holding containers with juvenile and pupal Aedes aegypti in Southern Taiwan: a cross-sectional study using hurdle model analyses. PLoS Negl Trop Dis 12(10):e0006882. https://doi. org/10.1371/journal.pntd.0006882

29. Walker KR, Williamson D, Carrière $Y$, Reyes-Castro PA, Haenchen $S$, Hayden MH, Jeffrey Gutierrez E, Ernst KC (2018) Socioeconomic and human behavioral factors associated with Aedes aegypti (Diptera: Culicidae) immature habitat in Tucson, AZ. J Med Entomol 55(4):955-963. https://doi. org/10.1093/jme/tjy011 
30. Liu Q, Guo Y, Lai S et al (2016) Coexistence of Aedes aegypti and Aedes albopictus in Jinghong City, Yunnan Province: a survey of Aedes aegypti invasion. J Trop Dis 4:1-6

31. Tsuda Y, Maekawa Y, Ogawa K, Itokawa K, Komagata O, Sasaki T, Isawa H, Tomita T, Sawabe K (2016) Biting density and distribution of Aedes albopictus during the September 2014 outbreak of dengue fever in Yoyogi park and the vicinity of Tokyo metropolis, Japan. Jpn J Infect Dis 69(1):1-5. https://doi.org/10.7883/yoken.JID.2014.576

32. UCLA (2020) Zero-inflated Poisson regression |R data analysis examples. https://stats.idre.ucla.edu/r/dae/zip/. Accessed 28 Sep 2020

33. UCLA (2020) Zero-inflated negative binomial regression | $R$ data analysis examples. https://stats.idre.ucla.edu/r/dae/zinb/. Accessed 28 Sep 2020

34. Zeileis A, Kleiber C, Jackman S (2008) Regression models for count data in R. J Stat Softw 27(8):1-25. https://doi.org/10.18637/jss.v027.i08

35. CRAN (2020) CRAN - Package AlCcmodavg. https://cran.r-project.org/web/ packages/AICcmodavg/index.html. Accessed 28 Sep 2020

36. Chaves LF, Keogh CL, Nguyen AM, Decker GM, Vazquez-Prokopec GM, Kitron UD (2011) Combined sewage overflow accelerates immature development and increases body size in the urban mosquito Culex quinquefasciatus. J Appl Entomol 135(8):611-620. https://doi.org/10.1111/ j.1439-0418.2010.01580.x

\section{Publisher's Note}

Springer Nature remains neutral with regard to jurisdictional claims in published maps and institutional affiliations.

\section{Submit your manuscript to a SpringerOpen ${ }^{\odot}$ journal and benefit from:}

- Convenient online submission

- Rigorous peer review

- Open access: articles freely available online

High visibility within the field

Retaining the copyright to your article

Submit your next manuscript at $\boldsymbol{\nabla}$ springeropen.com 